\title{
ASSESSMENT OF TOURIST TRAFFIC IN TATRA NATIONAL PARK IN 2018-2020
}

Krzysztof Paweł Borkowski, PhD (ORCID: 0000-0001-8122-525X)

Elżbieta Chowaniec, MSc (ORCID: 0000-0002-9339-4699)

Marek Durmała, MSc (ORCID: 0000-0003-4372-4159)

Marcin Kubasiak, BEng, MSc (ORCID: 0000-0002-4306-3605)

- The University College of Tourism and Ecology, Poland

Correspondence address:

Zamkowa 1, 34-200, Sucha Beskidzka, Poland

e-mail: szkola@wste.edu.pl

ABSTRACT: The aim of the article is to analyse the qualitative and quantitative research conducted between 2018 and 2020 in the field of tourist traffic in the Tatra National Park. The data presented in the article focuses on the situation of limitations to spatial mobility. To show the impact of changes in terms of implementation and meeting the needs of tourist trips, the period leading up to the outbreak of the SARS-CoV-2 virus pandemic was thoroughly studied, with a period marked by severe mobility restrictions. The obtained data made it possible to present the relationship between the restrictions and satisfying mentioned needs, which is visible in the example of the number of tourists visiting the Tatra National Park in the sections of 2020, which were characterised by a different scope of restrictions on social mobility.

KEYWORDS: Tatra National Park Poland, Tourist Traffic, Net Fear Score, Net Promoter Score, the pandemic of SARS-CoV-2 


\section{Introduction}

The aim of the article was to show the possibility of using quantitative and qualitative research on tourism in the Małopolska province to create its characteristics (quantitative and qualitative) in a smaller territorial unit of the studied province, which is precisely delimited to the area of the Tatra National Park and to verify the thesis initially "that the more human needs are impossible to satisfy during the normal daily rhythm of life, the faster appears the need to leave the environment in which he is subject to restrictions (probably the most burdensome for a human being are social restrictions), and go to a place far enough from the place of permanent residence to become a socially anonymous individual, and thus to be able to realise and satisfy the needs that he could not or was not allowed to satisfy in the daily environment" in terms of extreme conditions caused by SARS-CoV- 2 .

In the years 2018-2020, the Małopolska Tourist Organisation conducted a study of tourist traffic in Małopolska, which is one of the Polish voivodeships where tourism plays an important role in the social and economic sector, as part of its statutory tasks, which include "taking measures to increase the number of tourists visiting the Małopolska Voivodeship." Data (2018 $\mathrm{n}=594,2019 \mathrm{n}=631,2020 \mathrm{n}=663$ ) on the volume and quality of tourist traffic in the Tatra National Park were extracted from a database derived from survey research conducted among the tourists in the Małopolska province in 2018-2020 with an annual representative sample of a minimum of $n=5,400(2018 n=7,200,2019 n=7,019,2020 n=5,400)$.

The second group of tools (desk research methods) was based on publicly available data. These were mainly quantitative data collected from the management of the Tatra National Park, as well as from the Regional Data Bank and communiqués, bulletins, electronic publications (including archival data) published by the General Office of Statistics.

The study of the stream of tourist traffic in the Tatra National Park area over two years (2018-2019) preceding the year 2020 marked by severe limitations of social mobility caused by the WHO-announced SARS-CoV-2 virus pandemic showed the quantitative and qualitative picture of the stream of tourist traffic in the analysed period and at the same time gave the possibility to confirm that indeed the dependence of the "escape" from urbanised spaces into non-degraded spaces of the Tatra National Park occurs. The "escape" of the inhabitants of big cities into the open and non-degraded space of the trails in the Tatra National Park in 2020 was clearly marked.

This change in 2020 relative to the 2018-19 average was 15.35 p.p. in TNP. The results introduce a new point of view in the discussion on the management of visitors' stays in the Tatra National Park, through an annual or 
even biannual (winter season/summer season) comparative analysis of the presented visitors' segmentations with the preferred travel types and/or purchased services accompanying their stay taking into account the means of transport used in the trip. In the international context, we emphasise the importance of the Małopolska Tourist Organization's technology for studying tourist phenomena, which has been proven as a valuable tool in profiling tourists since 2004, and we highlight the issue of the need to monitor their subjective feelings and opinions when visiting special places in protected areas as part of mass tourism.

\section{Literature review}

The research was conducted by experts from the Intercollegiate Scientific Team of the Małopolska Tourist Organisation, based on an original method that enables comparative analysis of the volume and structure of tourism (Borkowski et al., 2021). Thanks to the integration of quantitative and qualitative data and the continuity of observation of the phenomenon, the research results are the excellent starting material for undertaking activities stimulating sustainable tourism development in specific areas of the Małopolska Voivodeship. Based on the conducted research, material on the stay of tourists in the Tatra National Park in 2018-2020 were extracted.

This research allows "understanding the motivations and behaviours of visitors to protected areas which is crucial for the effective management of vulnerable areas (Taczanowska et al., 2019). They signal that it is the analysis and understanding of tourism phenomena that need reliable techniques to support the management of tourism destinations. Segmentation is a widespread approach to reducing the complexity of visitor characteristics and behaviour. In many cases, the services generated by natural protected areas in general and National Parks, in particular, are "invisible" to the market, as they lack an assigned price (Sotelo Navalpotro et al., 2012). Tourist Traffic is used to put a monetary value which settles the value to heritage and encourages the public and private sectors for its conservation. This has been reflected in the new national and international regulations, which recognises tourist use among its main management objectives. At the same time, from an environmental perspective, the development of tourism gives rise to a series of negative externalities that may affect the conservation of these areas if the "load capacity" of these is not taken into consideration.

Research by the Małopolska Tourist Organization comes to the aid of administrators of specific tourist destinations. The problem was diagnosed in 2010 by the TNP director, writing that "during the fifty years of the Tatra National Park, there has been a tremendous increase in tourist traffic. Since 
1993, when the sale of entrance tickets to the park was introduced, we have reliable data on the volume of entrance traffic. They allow us to assess the volume of traffic in spatial (based on information from seventeen ticket sales points) and temporal (weekly, monthly and yearly) variation" (Skawiński, 2010). However, there has been a lack of separate, systematic and based on a representative sample, qualitative studies of park visitors in this area until now.

\section{Methodology of studying tourist traffic in the Małopolska region, including tourist stays in the Tatra National Park}

The data collection system adopted in the research was based on two main methods: face-to-face interviews conducted by interviewers using a paper questionnaire (PEPI - Paper and Pencil Interviewing) and desk research. Those methods allowed the Tatra National Park to conduct extensive quantitative and qualitative research on tourist traffic in 2018-2020. In addition, the triangulation of research methods used increases the quality of the research and significantly reduces measurement error.

The survey included visitors to the Tatra National Park who were classified as tourists (staying at least one night) and one-day visitors by the United Nations World Tourism Organization (UNWTO) for cognitive, recreational, professional, religious, family, health, and other reasons.

Domestic and foreign visitors, who declared a stay exceeding 90 days, were omitted from the study. Also, the leisure activity of Małopolska residents permanently working or studying in the Małopolska region and foreigners residing in Poland was considered. People from these categories constitute an important part of the tourist traffic stream and are not only direct tourist service staff but are also active tourists using the region's leisure offer.

The minimum sample size and sampling frame were based on 2017 Central Statistical Office (CSO) data on the use of collective accommodation facilities.

It was determined that a sample size of a minimum of $n=5,400$ people guarantees an estimation accuracy of $1.5 \%$. The size of the sample taken and verified for further analysis in the Małopolska province was in 2018 $n=7,200$, in $2019 n=7,019$, in $2020 n=5,400$ from which data were extracted for TNP from $2018 n=594$, from $2019 n=631$ and from $2020 n=663$ which gave a total of 1,888 questionnaires on the size and quality of tourist traffic in the Tatra National Park. A stratified sampling scheme was adopted for the general sample, where the stratum was the county and the type of facility in each county (hotels, motels, guesthouses, tourist homes, youth hostels, holi- 
day resorts, guest rooms, camping sites, campgrounds, holiday camps, other facilities) in proportion to the number of overnight visitors. Additionally, places of concentration of travellers such as railroad and bus stations, airports and tourist attractions were indicated for sampling. Experts determined the list of these places based on information obtained from employees of the tourism sector, guides, operators of tourist attractions, organisers of tourist traffic, customs service, and the Balice International Airport. The following rules were adopted for sampling: all persons interviewed were 16 years of age or older; in the case of family surveys, only one family member was interviewed; in the case of organised groups, at most two adults from the group were interviewed.

Surveys were conducted from January to November 2018 and 2019, and in 2020 (with a break in survey collection from March to May) according to the accepted sampling sites distribution for each month. In the last measurement year (2020), due to the SARS-CoV-2 virus pandemic, survey collection and sampling site selection were variable and dynamic. It largely depended on the collection of questionnaires from both foreign and domestic tourists staying in open spaces. More than 20 thousand respondents were surveyed during the entire research period, and 19619 questionnaires were qualified to the database after substantive verification. Each record (questionnaire saved in the database) contained a maximum of 293 elements (variants of answers to 42 questions contained in the questionnaire) plus 19 metric questions (a total of 333 elements). The smallest number of questionnaires (over 5450) was collected in 2020, of which 5400 records were analysed after verification. The work of interviewers in 2020 under severe pandemic conditions was efficient, resulting in a large number of correctly retrieved surveys. Questionnaires were entered into the database through a form on an html page and using script coded in scripting programming language PHP.

The second group of tools (desk research) was based on commonly available data. First of all, it was quantitative data coming directly from Tatra National Park management, as well as from Regional Data Bank and communiqués, bulletins, electronic publications (including archival data) provided by Central Statistical Office.

\section{Profile of tourists visiting the Tatra National Park surveyed in 2018-2020}

There was a significant change in the structure of visitors to TNP in 2020 in favour of permanent residents. According to the data in table 1, there was a 13.5 percent change in the mentioned structure in 2020 compared to the 2018-19 average. This was undoubtedly influenced by the Polish state bor- 
ders being closed to foreigners from 13.03 .2020 as a consequence of the decision of March 11 2020, when the World Health Organisation (WHO) declared a series of cases of respiratory infectious disease caused by the SARS-CoV-2 virus infection, as a pandemic.

Table 1. Percentage structure of tourists visiting the Tatra National Park surveyed in 2018-2020 in terms of their declared country of permanent residence (Country - Foreign)

\begin{tabular}{llllll}
\hline TNP & \% vertical & \% vertical & \% vertical & $\begin{array}{l}\text { Average } \\
\mathbf{1 8 - 1 9}\end{array}$ & $\begin{array}{l}\text { Change in 2020 relationship } \\
\text { to averages 18-19 }\end{array}$ \\
\hline Year & 2018 & 2019 & 2020 & 84.5 & 13.5 p.p. \\
\hline Country & 90.2 & 78.8 & 98.0 & 15.5 & -13.5 p.p. \\
\hline Abroad & 9.8 & 21.2 & 2.0 & 100.0 & 0.0 p.p. \\
\hline Total & 100.0 & 100.0 & 100.0 & & \\
\hline
\end{tabular}

Source: own study.

In 2020, there was a clear "flight" of big-city residents into the Tatra National Park's open non-degraded trail space. According to the table below, the change in 2020 compared to the 2018-19 average was 15.35 p.p.

Table 2. Percentage structure of tourists visiting the Tatra National Park surveyed in 2018-2020 by the size of their declared place of permanent residence

\begin{tabular}{llllll}
\hline TNP & \% vertical & \% vertical & \% vertical & $\begin{array}{l}\text { Average } \\
18-19\end{array}$ & $\begin{array}{l}\text { Change in 2020 relationship } \\
\text { to averages 18-19 }\end{array}$ \\
\hline Year & 2018 & 2019 & 2020 & 21.25 & 15.35 p.p. \\
\hline Big city & 26.5 & 16.0 & 36.6 & 32.95 & 2.75 p.p. \\
\hline Town & 28.1 & 37.8 & 35.7 & 28.71 & -5.11 p.p. \\
\hline Big town & 30.6 & 26.8 & 23.6 & 12.25 & -8.85 p.p. \\
\hline Big village & 9.0 & 15.5 & 3.4 & 4.85 & -4.15 p.p. \\
\hline Small village & 5.8 & 3.9 & 0.7 & 100.0 & 0.0 p.p. \\
\hline Total & 100.0 & 100.0 & 100.0 & &
\end{tabular}

Source: own study.

Spatial mobility is a natural human trait, subject to many constraints over the course of human life. The longer these constraints operate, the more force it reveals once the sets of limiting factors weaken or disappear (Borkowski, 2019). There is a clear relationship between the degree of possibility of realisation and satisfaction of needs felt daily and the speed of appearance in a human of the need for a tourist trip (temporary change of the permanent 
living and working environment - permanent place of residence). The more needs of the human being are impossible to be satisfied during the normal daily rhythm of life, the faster the need to leave the environment in which he/ she is subject to limitations (the most burdensome of which are probably social limitations) and go to a place distant enough from the place of permanent residence to become a socially anonymous individual and thus realise and satisfy the needs that he or she could not or was not allowed to stay. Probably these, not always fully conscious, and unsatisfied needs imply the need to leave the place of permanent residence, including a tourist trip (Borkowski, Borkowska, 2005).

Analysing the data, declared by the tourists visiting Tatra National Park in 2018-2020 (table 3), about the places of their permanent residence as the country where they stay on a daily basis, it can be shown that the basic list of countries starts with two equal emission markets, that is, the United Kingdom and Germany. In 2020, a clear advantage was gained by tourists from Germany, who could also reach Małopolska by means of transport other than air travel. In this group, the change in 2020 in relation to the average of 18-19 amounted to 15.7 p.p., while visitors from the United Kingdom showed a decrease of almost 10 p.p. in 2020 in relation to the average of 18-19 (-9.6 p.p.). In 2020 there was a kind of compensation in the groups described above in relation to the average in 18-19, the result of which reached 6.1 p.p. The third place is invariably occupied ex aequo by tourists from Italy and Spain with an average result for three years $\approx 13 \%$ share in the stream of foreign inbound tourism to the Tatra National Park. Despite the pandemic situation in 2020 , the \% structure of the tourist stream for the top four countries proved to be stable, remaining at a similar level as in previous years consuming in 2020 (table 3) more than 70\% shares. A clear change in arrivals from France in relation to the 18-19 average of over 19 p.p. was noted in 2020. However, it should be remembered that the annual calculation of the size of the tourist stream visiting the Tatra National Park was strongly influenced by the sensational first quarter of 2020 (winter season), which was better than the first quarter and the record-breaking one for the Małopolska tourism industry in 2019.

More than half (53.4\%) of domestic tourists who visited the Tatra National Park in 2020 were residents of Małopolska (table 4) who decided to "Be a tourist at home - in their province". This is related, among others, today trips without an overnight stay, which was difficult, risky or even impossible. This is exemplified by the high all-day turnout recorded in Q4 2020 during the 20/21 winter season on the ski slopes of Małopolska. People who arrived late had a serious problem parking their cars. 
Table 3. Percentage structure of foreign tourists visiting the Tatra National Park surveyed in 2018-2020 in terms of their declared country of permanent residence

\begin{tabular}{llllll}
\hline Country & 2018 & 2019 & 2020 & $\begin{array}{l}\text { average } \\
18-19\end{array}$ & $\begin{array}{l}\text { Change in 2020 } \\
\text { relationship } \\
\text { to averages 18-19 }\end{array}$ \\
\hline The United Kingdom & 28.9 & 21.0 & 15.4 & 24.9 & -9.6 p.p. \\
\hline Germany & 13.3 & 16.8 & 30.8 & 15.1 & 15.7 p.p. \\
\hline$\sum-1-$ intermediate & 42.20 & 37.80 & 46.20 & 40.00 & 6.10 p.p. \\
\hline Italy & 17.8 & 11.8 & 15.4 & 14.8 & 0.6 p.p. \\
\hline Spain & 15.6 & 10.1 & 15.4 & 12.8 & 2.6 p.p. \\
\hline$\sum-2-$ intermediate & 33.40 & 21.90 & 30.80 & 27.60 & 3.20 p.p. \\
\hline Slovakia & 4.4 & 9.2 & 0.0 & 6.8 & -6.8 p.p. \\
\hline Irleland & 6.7 & 5.9 & 0.0 & 6.3 & -6.3 p.p. \\
\hline Hungary & 4.4 & 5.0 & 0.0 & 4.7 & -4.7 p.p. \\
\hline Belgium & 4.4 & 4.2 & 0.0 & 4.3 & -4.3 p.p. \\
\hline France & 4.4 & 3.4 & 23.1 & 3.9 & 19.2 p.p. \\
\hline The Czech Republic & 0.0 & 7.6 & 0.0 & 3.8 & -3.8 p.p. \\
\hline Switzerland & 0.0 & 5.0 & 0.0 & 2.5 & -2.5 p.p. \\
\hline Final total & 100.0 & 100.0 & 100.0 & 100.0 & 0.0 p.p. \\
\hline
\end{tabular}

Source: own study.

However, under the prevailing pandemic threat conditions, they proved to be an excellent means of safe transportation, a place to consume victuals from their own picnic basket or purchased at the drive-through windows. It was noticed that in 2020, there would be a significant increase in tourist arrivals from the Silesian region, with a share of nearly $19 \%$. As presented in table 4, Silesians represent a very strong segment of the stream of tourist traffic to the Tatra National Park, which reached an average of $\approx 15 \%(14.77 \%)$ for the next three years of observation. In third place, ex aequo were tourists from Podkarpacie and Mazowsze regions obtaining an average for the three analysed years of $\approx 9 \%, \approx 7 \%$ share, respectively. However, even though in 2020 tourists from Podkarpacie (9.1\%) overtook tourists from Mazovia by almost $2.5 \%$, there was a decrease in arrivals to the TNP from both Podkarpacie and Mazovia, which can be explained by the increased tourist travels of Mazovia residents within their own province as well as towards Warmia and Mazury region, and the travels of the Małopolska residents largely included the areas of the Bieszczady National Park. 
Table 4. Percentage structure of domestic tourists visiting the Tatra National Park surveyed in 2018-2020 in terms of their declared province of permanent residence

\begin{tabular}{llllll}
\hline Voivodeship & 2018 & 2019 & 2020 & $\begin{array}{l}\text { Average } \\
18-19\end{array}$ & $\begin{array}{l}\text { Change in } 2020 \\
\text { in relation } \\
\text { to 18-19 average }\end{array}$ \\
\hline Małopolskie & 40.2 & 42.3 & 53.4 & 41.26 & 12.12 p.p. \\
\hline Śląskie & 11.8 & 13.7 & 18.8 & 12.74 & 6.03 p.p. \\
\hline Podkarpackie & 10.3 & 11.7 & 5.2 & 10.99 & -5.76 p.p. \\
\hline Mazowieckie & 8.4 & 6.5 & 4.9 & 7.43 & -2.51 p.p. \\
\hline Wielkopolskie & 5.8 & 5.4 & 2.9 & 5.62 & -2.70 p.p. \\
\hline Pomorskie & 5.2 & 3.2 & 1.2 & 4.23 & -3.00 p.p. \\
\hline tódzkie & 5.6 & 2.8 & 2.6 & 4.22 & -1.60 p.p. \\
\hline Świętokrzyskie & 3.4 & 3.2 & 3.5 & 3.30 & 0.24 p.p. \\
\hline Dolnośląskie & 2.8 & 2.2 & 2.3 & 2.51 & -0.20 p.p. \\
\hline Kujawsko-pomorskie & 3.6 & 1.4 & 0.5 & 2.48 & -2.02 p.p. \\
\hline Opolskie & 1.1 & 1.4 & 1.8 & 1.27 & 0.58 p.p. \\
\hline Zachodniopomorskie & 0.7 & 1.6 & 0.9 & 1.18 & -0.26 p.p. \\
\hline Lubelskie & 0.4 & 1.8 & 1.1 & 1.09 & -0.02 p.p. \\
\hline Podlaskie & 0.7 & 1.2 & 0.0 & 0.98 & -0.98 p.p. \\
\hline Lubuskie & 0.0 & 1.2 & 0.5 & 0.60 & -0.14 p.p. \\
\hline Warmińsko-mazurskie & 0.0 & 0.2 & 0.3 & 0.10 & 0.21 p.p. \\
\hline Total & 100.0 & 100.0 & 100.0 & 100.00 & 0.00 p.p. \\
\hline & & & & &
\end{tabular}

Source: own study.

Subjective components of Client Relations Management and loyalty decision of visitors to Małopolska

\section{Evaluation of safety level before coming to Małopolska -} Net Fear Score index of visitors of Tatra National Park

The Net Fear Score (NFS) is an index of fear, anxiety, and fear of arriving at a destination. Borkowski K. developed NFS index in 2016 based on previous studies of Tourist Traffic in Krakow. It was implemented as a pilot during the study of Participants of World Youth Day 2016 in Krakow done by the Extended Intercollegiate Team of Experts of the Małopolska Tourist Organization (Borkowski et al., 2017). 
In its broadest sense, safety is very important for the development of tourism in the region. Thus, the surveyed visitors to Małopolska were asked to determine on an 11-point numerical scale the subjective level of their own fear and anxiety about coming to Małopolska, where: "0" meant that: I was not afraid at all, while 10 meant that I was full of fears. When the total results for the years 2018-2020 are examined, it can be seen that the largest group of TNP visitors declared a total of " 0 " level (mean of $18-19$ years $=\approx 70 \%$; and in 2020 with pandemic risk $\approx 46 \%$ ), that is, there was a serious change of mental attitude before coming to TNP by more than -25 p.p. in relation to the mean of 18-19 years. In the typical conditions, travellers consciously agree to increase the risk of life in favour of pursuing current goals for a limited time. In this way, a potential (natural?) human psychological barrier of fear of the unknown is broken down (neophobia). Then the person leaves the safe place of permanent residence, setting off into the unknown (Herzig, 1998).

Table 5. Subjective evaluation of the level of safety in the destination before deciding to travel to Małopolska by visitors to the Tatra National Park

\begin{tabular}{llllll}
\hline $\begin{array}{l}\text { Concerns about coming } \\
\text { to Małopolska/TNP }\end{array}$ & $\mathbf{2 0 1 8}$ & $\mathbf{2 0 1 9}$ & $\mathbf{2 0 2 0}$ & $\begin{array}{l}\text { Average } \\
\mathbf{1 8 - 1 9}\end{array}$ & $\begin{array}{l}\text { Change in 2020 } \\
\text { in relation to 18-19 }\end{array}$ \\
\hline 0 & 65.6 & 76.1 & 45.5 & 70.88 & -25.37 p.p. \\
\hline 1 & 8.2 & 18.1 & 23.1 & 13.18 & 9.89 p.p. \\
\hline 2 & 6.0 & 3.6 & 20.7 & 4.80 & 15.95 p.p. \\
\hline 3 & 3.7 & 0.2 & 8.0 & 1.96 & 6.09 p.p. \\
\hline 4 & 4.1 & 0.2 & 0.8 & 2.16 & -1.39 p.p. \\
\hline 5 & 1.9 & 0.0 & 0.6 & 0.93 & -0.31 p.p. \\
\hline 6 & 1.2 & 0.2 & 0.3 & 0.72 & -0.41 p.p. \\
\hline 7 & 2.5 & 0.0 & 0.5 & 1.23 & -0.77 p.p. \\
\hline 8 & 2.3 & 0.0 & 0.2 & 1.13 & -0.98 p.p. \\
\hline 9 & 1.2 & 0.4 & 0.2 & 0.83 & -0.68 p.p. \\
\hline 10 & 3.3 & 1.1 & 0.2 & 2.18 & -2.02 p.p. \\
\hline Final total & 100 & 100.0 & 100.0 & 100.00 & 0.00 p.p. \\
\hline NFS Index & 61.5 & 92.5 & 66.7 & 77.0 & -10.3 p.p. \\
\hline
\end{tabular}

Source: own study.

The indicated levels of fear have been aggregated. Travellers' fears and anxieties were indicated by the sum of the indications from the values " 5 " to "10". Those who marked states " 4 " - " 3 "-" 2 " on the numerical scale were con- 
sidered neutral, as people going on a trip try to protect themselves by preparing for the trip, and this means analysing possible threats occurring outside the place of permanent residence. The numerical scale values " 0 " and " 1 " represent the state of complete absence of fear and anxiety before arrival. They reflect the subjective feelings of people who are fully convinced that their trip to the Tatra National Park was at no time accompanied by a feeling of anxiety, fear or worry about their property, health and life.

Despite a spectacular decrease of more than 25 p.p. (table 5) in the feeling of the state of total safety when travelling to the Tatra National Park in 2020 , the NFS index for visitors to the TNP remained very high. It remained for the three analysed years at an average level of 73.6\%. An NFS index score above $50 \%$ is considered a success for the destination.

\section{Evaluation of the level of satisfaction from a stay in Małopolska - Net Promoter Score of visitors of the Tatra National Park}

The destination visitor satisfaction and loyalty index - Net Promoter Score, also known as the advocacy index - was used as the second contingency dimension. Net Promoter Score (NPS) is an indicator created by Reichheld F. It is used to measure consumer loyalty and the quality of relationships built with them. The essence of the indicator comes down to the study of the customer's propensity to recommend the product or service of a given brand. Regular monitoring of NPS level allows evaluating the quality of conducted activities and provides necessary information that facilitates planning strategies to build customer satisfaction. Optimally used it can be a tool to increase company's profits. (Gajewska, Szewczyk, 2012)

During surveying, respondents were asked: "how likely are they to recommend Małopolska to their friends". Responses were also given by visitors to the Tatra National Park using an 11-point scale, from 0 to 10 , where " 0 " meant no willingness to recommend, and " 10 " meant full loyalty and complete satisfaction with their stay in the destination.

It is assumed that a positive NPS index already indicates good standards, and with a score higher than $50 \%$, one can speak of success. In the analysed case, the NPS index for 2020 was $80 \%$, and the average of 2018-2019 $=74 \%$ (table 6). The change in 2020 in relation to the 18-19 average reached the level of 6 p.p. in plus which for the reception of tourists in the conditions of the epidemic condition is a very optimistic result of the level of satisfaction with the offer obtained tourists during their stay in TNP. 
Table 6. Subjective evaluation of the level of satisfaction from the stay in the destination by visitors to the Tatra National Park

\begin{tabular}{llllll}
\hline $\begin{array}{l}\text { Declaration of the TNP } \\
\text { recommendation }\end{array}$ & 2018 & 2019 & 2020 & $\begin{array}{l}\text { average } \\
18-19\end{array}$ & $\begin{array}{l}\text { Change in 2020 } \\
\text { in relation } \\
\text { to 18-19 average }\end{array}$ \\
\hline 0 & 0.4 & 1.4 & 0.0 & 0.90 & -0.90 p.p. \\
\hline 1 & 0.6 & 0.4 & 0.2 & 0.49 & -0.33 p.p. \\
\hline 2 & 0.0 & 0.2 & 0.0 & 0.10 & -0.10 p.p. \\
\hline 3 & 0.6 & 0.0 & 0.3 & 0.29 & 0.02 p.p. \\
\hline 4 & 0.4 & 0.0 & 0.2 & 0.19 & -0.04 p.p. \\
\hline 5 & 1.5 & 0.0 & 0.3 & 0.76 & -0.45 p.p. \\
\hline 6 & 2.7 & 0.2 & 0.5 & 1.44 & -0.97 p.p. \\
\hline 7 & 7.1 & 1.4 & 5.1 & 4.25 & 0.88 p.p. \\
\hline 8 & 20.1 & 6.7 & 12.0 & 13.40 & -1.42 p.p. \\
\hline 9 & 10.5 & 34.4 & 41.8 & 22.47 & 19.37 p.p. \\
\hline 10 & 56.2 & 55.2 & 39.7 & 55.70 & -16.05 p.p. \\
\hline NPS & 60.50 & 87.40 & 80.00 & 74.00 & 6.09 p.p. \\
\hline
\end{tabular}

Source: own study.

Declaration of revisiting the Tatra National Park by visitors to TNP

Analysing the respondents' answers on their declaration to come to the Tatra National Park again (table 7), in 2020, the vast majority of respondents answered affirmatively: "rather yes" (54.4\%), "definitely yes" (35.5\%), which is $\approx 90 \%$ (89.9\%) of the surveyed people. The group of undecided people who answered "don't know" in 2020 reached almost $10 \%$ of the shares of the tourist stream (9.9\%), achieving a result of a change in relation to the average of 2018-2019 by almost 5 p.p. (4.99 p.p.). People who declared that they would not travel to the Tatra National Park again in 2020 were virtually non-existent: "definitely not" $(0.0 \%)$ and "rather not" $(0,2 \%)$. 
Table 7. Declaration of return of visitors to the Tatra National Park in percent

\begin{tabular}{llllll}
\hline Declaration of revisiting & 2018 & 2019 & 2020 & $\begin{array}{l}\text { average } \\
18-19\end{array}$ & $\begin{array}{l}\text { Change in 2020 } \\
\text { in relation } \\
\text { to 18-19 average }\end{array}$ \\
\hline definitely yes & 68.6 & 57.3 & 35.5 & 62.93 & -27.41 p.p. \\
\hline rather yes & 25.8 & 36.8 & 54.4 & 31.26 & 23.14 p.p. \\
\hline don't know & 4.9 & 4.9 & 9.9 & 4.93 & 4.99 p.p. \\
\hline rather not & 0.0 & 1.0 & 0.2 & 0.51 & -0.35 p.p. \\
\hline definitely no & 0.8 & 0.0 & 0.0 & 0.38 & -0.38 p.p. \\
\hline final total & 100.0 & 100.0 & 100.0 & 100.00 & 0.00 p.p. \\
\hline
\end{tabular}

Source: own study.

\section{Attendance on Tatra National Park trails in 2020}

It is visible in figure 1 how the administrative decisions of the state in connection with the epidemic regulations influenced the size of the stream of tourist traffic in the Tatra National Park. For example, when the lockdown was announced from March 13 to mid-May 2020, practically only two entrances to TNP were accessible (Dolina Białego and Dolina Strążyska). Also, the last months of 2020 (November and December) were at almost zero level compared to the summer season.

This data confirms the MOT study presented in table 8, showing the phenomenon of compensating tourist flow during June, July, August, and proving at the same time the power of "accumulated deferred needs" that are revealed in society immediately when the restrictions block them are lifted.

The survey of tourists done by the MOT expert method within the Tatra National Park was conducted on a total sample of 1888 respondents in 2018 (594 people), 2019 (631 people), 2020 (663 people). TNP statistics from this period show that between 2018 and 2020, a total of $10,628,459$ people were admitted to the park with tickets of which in $2018-3,782,610$ people, in $2019-3,782,610$ people and in $2020-3,301,895$ people. The annual average of admissions to the TNP for 2018-19 is 3782610 people who, in relation to the number of admissions to the Tatra National Park from the year 2020 (with the total blockade of admission to the park in April and May) gives only less than half a million (480 715) people less. 


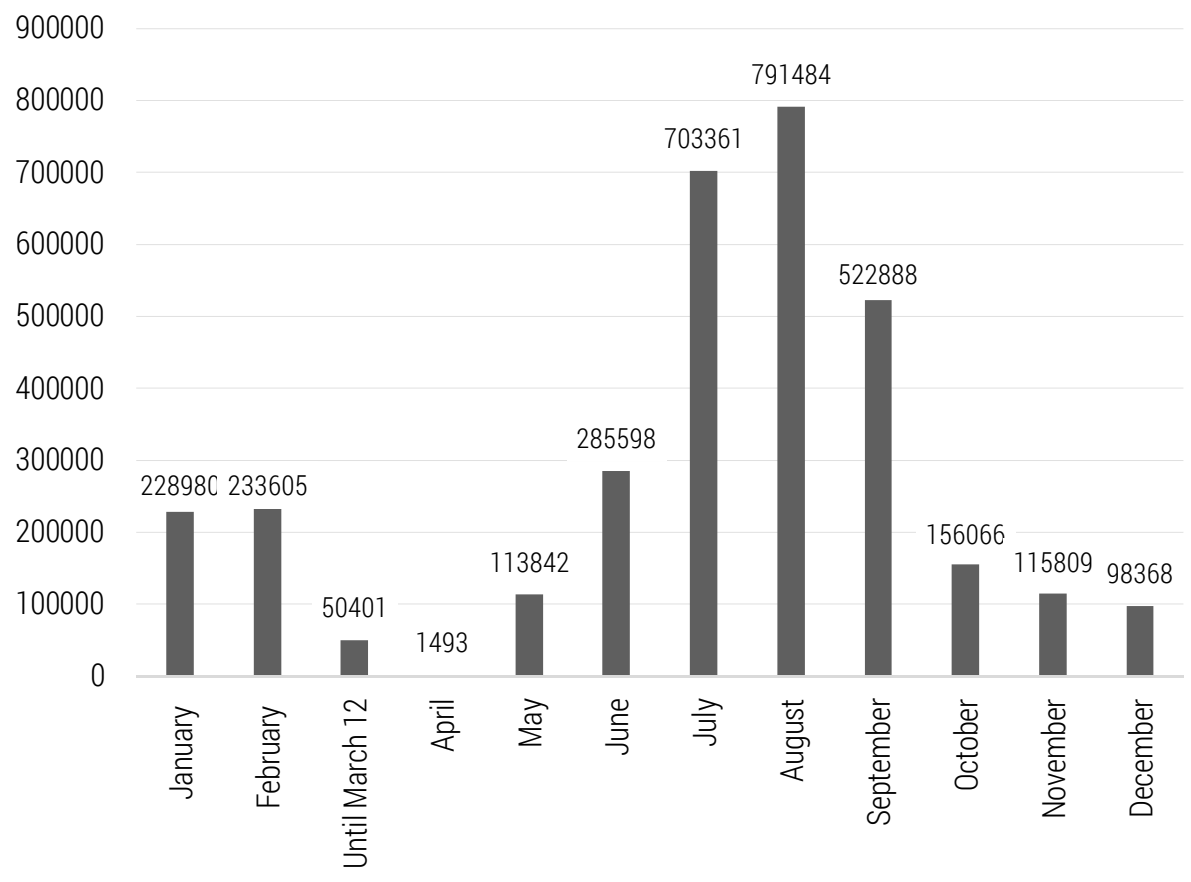

Figure 1. TNP admissions statistics in 2020 by month - sold tickets

Source: Own elaboration based on: Tatra National Park Directorate https://tpn.pl/zwiedzaj/turystyka/ statystyka.

Table 8. Monthly structure of tourist attendance in percent in the Tatra National Park in 2020

\begin{tabular}{llll}
\hline Month & $\mathbf{2 0 2 0}$ & Average 18-19 & $\begin{array}{l}\text { Change in 2020 } \\
\text { in relation to 18-19 average }\end{array}$ \\
\hline 1 & 5.0 & 3.98 & 1.00 p.p. \\
\hline 2 & 11.5 & 9.55 & 1.91 p.p. \\
\hline 3 & 3.8 & 3.71 & 0.06 p.p. \\
\hline 4 & 0.0 & 1.48 & -1.48 p.p. \\
\hline 5 & 0.0 & 7.28 & -7.28 p.p. \\
\hline 6 & 21.1 & 4.35 & 16.77 p.p. \\
\hline 7 & 19.5 & 9.69 & 9.77 p.p. \\
\hline 8 & 25.6 & 17.72 & 7.92 p.p. \\
\hline 10 & 11.3 & 11.84 & -0.52 p.p. \\
\hline
\end{tabular}




\begin{tabular}{llll}
\hline Month & 2020 & Average 18-19 & $\begin{array}{l}\text { Change in 2020 } \\
\text { in relation to 18-19 average }\end{array}$ \\
\hline 11 & 0.0 & 15.85 & -15.85 p.p. \\
\hline 12 & 0.0 & 4.45 & -4.45 p.p. \\
\hline Final total & 100.0 & 100.00 & 0.00 p.p. \\
\hline
\end{tabular}

Source: own study.

\section{Discussion}

Delekta et al. (Delekta et al., 2020) write that "increasing human impact in mountain areas may constitute a challenge to national park authorities," implying the importance of monitoring the most valuable areas, including but not limited to national parks, particularly the Tatra National Park. Therefore, interdisciplinary research is important in order to address the various aspects of the functioning of protected areas.

Similarly, notes (Klimek, 2017), writing that "since the second half of the 19th century, mountain tourism has contributed to the development of international tourism and, according to estimates, annually generates about $15-20 \%$ of revenues generated from tourism worldwide (UNEP, 2007). Despite the great diversity of offerings, since the mid-1960s, there has been a noticeable stagnation of summer tourism in many mountain regions, in contrast to well-developed winter tourism." She signals, however, that "research on the development of summer tourism in mountain regions is rarely presented in scientific studies in Poland and abroad". In her article, she showed the role of local and regional tourism organisations (DMOs) in stimulating summer mountain tourism through diversified product strategies. The systematic quantitative and qualitative research on tourism phenomena, conducted since 2003 by the Małopolska Tourist Organization, the regional Destination Management Organizations (DMOs), fits in with this way of looking at the problem.

In terms of sample size and thematic scope of questions included in the survey, the data presented in this article are unique in the country. The data were extracted specifically to present the problem and demonstrate how they could be used to help manage a well-defined tourist reception area.

Mountain tourism, which began in the nineteenth century, has a very strong capital attraction for international tourist flow and represents approximately 15-20\% of annual global tourism income (UNEP, 2007). Although a huge variety of activities has been offered in numerous mountain destinations since the mid-1960s, summer tourism stagnates, unlike winter tourism 
(France Montagne, 2014; Nydegger, 2014). Nevertheless, signals that studies concerned with summer tourism development in mountain regions are rare. The paper presents the result of a comparative study conducted between 2013, 2014 and 2015 in 183 local and regional Destination Management Organisations (DMOs) operating in selected European and North American mountain areas to understand their role in the stimulation of summer tourism through various product commercialisation strategies.

Systematic quantitative and qualitative studies of tourism phenomena carried out since 2003 by the Małopolska Tourist Organization as regional Destination Management Organizations (DMOs) fit in with this way of looking at the problem.

Apart from obtaining detailed data on the flow of tourist traffic, a very important element resulting from the research carried out is the analysis of its social aspects (NFS and NPS indicators). The presented data confirm that the needs of tourist trips accumulated in the period characterised by the lack of mobility are satisfied as soon as possible. The data on tourist traffic confirm this in individual months of 2020 presented in figure 1 . This phenomenon is particularly visible during the summer season when restrictions on social mobility have been partially limited or lifted. A very important aspect related to the course of changes in the field of movement in space are also issues related to environmental protection.

The SARS-CoV-2 virus pandemic, on the one hand, had a large, negative impact on society and the comfort of its functioning; on the other hand, positive effects on the natural environment characterised it. In the case of the Tatra National Park, the most important thing to mention is the ecological renovation of tourist destinations (Hrytsai, 2021). The drastically reduced number of tourists using the trails located in the Tatra National Park in particular periods of 2020 provided the possibility of ecological regeneration of this area. The comparative data on the number of tourists visiting the protected area in individual months in 2018-2020 clearly shows that the period in which tourist traffic is low significantly extended in 2020, and thus the period was extended in which tourists do not directly influence of the natural environment.

\section{Conclusions}

The space of the Tatra National Park with its tourist function proved in the pandemic year 2020 resistant to the most restrictive limitations of social mobility. Active tourism, requiring individual skills to practice it, selected the stream of tourist participants reaching the territory of TNP. Therefore, this destination was particularly frequented by residents of very large cities, 
followed by residents of large cities. This part of the population felt most the lack of access to natural or nature-like geographical space, which is extremely difficult to find in cities, especially very large ones. Feelings of fear for one's health and life kept most people with sufficient daily contact with the natural environment (inhabitants of villages and small towns) in their permanent residence, as well as people with a low sense of security who most often used the commercial offer of holidays or travel agencies. At the same time, people who could prepare their own trips for themselves and their families used their skills in partner trips with a strong emphasis on qualified tourism. An excellent area for such trips is the Tatra National Park.

Despite the fact that the index of fear of NFS departure dropped strongly in 2020 to the level of less than $67 \%$, it turns out that the same respondents, already being on the spot and using the offer that TNP, together with other managers of the Tatra Mountains tourist base and attractions, prepared for them, gave a very high rating to the Tatra National Park, because the MPS index, which is measurable proof of individual satisfaction with the stay on the trails of TNP in 2020 was $80 \%$. Also, the declaration of coming to the Tatra National Park again reached $90 \%$ of indications for YES, with $10 \%$ of hesitant people. After the removal of administrative restrictions in the summer season (June, July, August), there was a cumulative realisation of the "needs set aside" by the public during the recommended and sometimes forced "quarantine" in the place of permanent residence, which was clearly manifested in the intensity of the stream of tourist traffic in the Tatras, including the area of the TNP. This proves that once the possibility of SARS-CoV-2 infection is controlled and eliminated, tourism in the Małopolska region, especially in areas least degraded by civilisation, such as the Tatra National Park, will develop very dynamically.

The unique results of quantitative and qualitative research in the Tatra National Park, presented in this paper, are only a signal margin of the possibilities offered by the tourism database collected by the Małopolska Tourist Organization concerning the phenomena accompanying the penetration of the province by participants in both domestic and foreign tourism. Applying the method developed by the Intercollegiate Team of Experts of the Małopolska Tourist Organization to other regions (voivodeships) would allow comparative analyses of other destinations in similar periods according to the same parameters and indicators. As a result, it would be possible to obtain a complete picture of Poland as a Tourism Reception Area (Żemła, 2010; Seweryn, 2012), i.e. a destination for domestic and foreign tourists. The authors suggest that the described quantitative and qualitative research method on tourism participants be applied not only in other regions of Poland but also in other countries of the world (Borkowski, Grabińska, Seweryn, 2016). 


\section{The contribution of the authors}

Individual contribution of the authors:

Conceptualization - Borkowski Krzysztof - 100\%

Methodology - Borkowski Krzysztof - 100\%

Software - Kubasiak Marcin - 70\%, Borkowski Krzysztof - 30\%

Validation - Kubasiak Marcin - 60\%, Durmała Marek - 40\%

Formal analysis - Borkowski Krzysztof - 50\%, Kubasiak Marcin - 25\%,

Durmała Marek - 25\%

The Investigation - Durmała Marek - 50\%, Chowaniec Elżbieta - 50\%

Resources - Borkowski Krzysztof - 70\%, Durmała Marek - 30\%

Data protection - Kubasiak Marcin -70\%, Chowaniec Elżbieta - 30\%

Writing - original draft - Borkowski Krzysztof - 40\%, Durmała Marek - 20\%,

Kubasiak Marcin - 20\%, Chowaniec Elżbieta - 20\%

Writing - review and editing - Borkowski Krzysztof - 50\%, Durmała Marek - 20\%, Chowaniec Elżbieta - 30\%

Visualization - Kubasiak Marcin - 80\%, Chowaniec Elżbieta - 20\%

Supervision -Chowaniec Elżbieta - 40\%, Borkowski Krzysztof - 60\%

\section{References}

Borkowski, K., 2000. Untersuchung der Beurteilung touristischer Leistungen durch Touristen, die Polen Besuchen. Das Bild der Qualittat und Art Ihrer Übermittlung. In: Matlović R. (Ed.) Urbánne a krajinne štūdie NR 3 Urbánny vŷvoj na rozhrani milènii. Filozoficka fakulta Presowskiej unverzity Instytut turizmu a hotelowego manazmentu, University in Prešov, 355-365.

Borkowski, K., 2019. Triangulacja subiektywnych odczuć osób wypoczywających w Krakowie w aspekcie poczucia bezpieczeństwa osobistego podczas rekreacyjnego pobytu w destynacji, Małopolska Organizacja Turystyczna, Kraków.

Borkowski, K., Grabiński, T., Seweryn, R., Mazanek, L., Alejziak, B., Grabińska, E., 2021. Ruch Turystyczny w Małopolsce w 2020 Roku - Wersja pełna - Monografia Numer 2 /2021. Małopolska Organizacja Turystyczna, Kraków.

Borkowski, K., 2019. Triangulacja subiektywnych odczuć osób wypoczywających w Krakowie w aspekcie poczucia bezpieczeństwa osobistego podczas rekreacyjnego pobytu w destynacji. Małopolska Organizacja Turystyczna, Kraków.

Borkowski, K., Borkowska, D., 2005. Cywilizacyjne uwarunkowania turystycznych form odnowy psychosomatycznej - zagrożenia cywilizacyjne a turystyka. In: Gotowt-Jeziorska, A., Wyrzykowski J. (Ed.) Turystyka a uzdrowiska. Polskie Stowarzyszenie Turystyki PST, Warszawa, 28-32.

Borkowski, K., Grabiński, T., Seweryn, R., Mazanek, L., Jackowski, A., Ostrowski, M., Bogacz, R., Bilska-Wodecka, E., Sołjan, I., Łabaj, M., Alejziak, B., Grabińska, E., Mróz, F., Sobczuk, J., Liro, J., 2017. Uczestnicy Światowych Dni Młodzieży w Krakowie w 2016 roku: Ruch Turystyczny w Krakowie 2016 Numer 2/2017: monografia. Małopolska Organizacja Turystyczna, Kraków, http://www.mot. 
krakow.pl/media/badanie-ruchu-turystycznego/16-08-2017-sdm_-isbn --do-tlumaczenia-z-bibliografia.pdf [29-03-2021].

Borkowski, K., Grabińska, E., Seweryn, R., 2016. Implementation of Tourist Mobility Research model in an integrated study of tourist traffic in Polish metropolitan cities. In: Pachrova, S., Dolezalova, M. (Ed.) Aktualni problemy cestovniho ruchu "Mistni bohatstvi a cestovni ruch" : recenzovany sbornik z mezinarodni konference, Jihlava, 24th and 25th of February 2016 = Topical Issues of Tourism "Local heritage and tourism": peer-reviewed conference proceedings of the International Conference, Vysoka skola polytechnicka, Jihlava, 41-50.

Delekta, A., Fidelus-Orzechowska, J., Chrobak, A., 2020. Expert's Perceptions towards Management of Tourist Traffic in Protected Areas Based on the Tatra Mountains. Journal of Environmental Management and Tourism, (Volume XI, Spring), 2(42), https://doi.org/10.14505//jemt.v11.2(42).23.

Gajewska, P., Szewczyk, I., 2012. Wskaźnik NPS w ocenie lojalności i satysfakcji konsumenckiej usług wybranych punktów gastronomicznych na terenie Żywca. Zeszyty Naukowe Uniwersytetu Szczecińskiego. Ekonomiczne Problemy Usług nr 84 (699), Popyt turystyczny: konsumpcja-segmentacja-rynki, 409-420.

Herzig, M., 1998. Dynamika potrzeb turysty zorganizowanego. In: Nowakowska A. (Ed.), Turystyka w środowisku społecznym i gospodarczym: konferencja poświęcona pamięci profesora Romana Peretiatkowicza, Kraków - Sucha Beskidzka, 20-22 maja 1996, Zesz. Nauk. / AWF Krak., nr 75, Akademia Wychowania Fizycznego w Krakowie, Kraków, 117-120.

Hrytsai, L., 2021. The Positive and Negative Effects of COVID-19 Pandemic on the Natural Environment in the World. Security theory and practice No. 2 (XLIII), 69-89, https://doi.org/10.48269/2451-0718-btip-2021-2-004.

Klimek, K., 2017. The Role of Destination Management Organizations (DMOs) in Commercialisation of Summer Tourism Products. New Challenges for Mountain Destinations in an Integrated and Global e-Market Place. Ekonomiczne Problemy Turystyki nr 4 (40), 19-28, https://doi.org/10.18276/ept.2017.4.40-02.

Seweryn, R., 2012. Kreowanie wartości dla klienta przez obszar recepcji turystycznej. Wydawnictwo Uniwersytetu Ekonomicznego w Krakowie, Kraków.

Skawiński, P., 2010. Zarządzanie ruchem turystycznym w Tatrzańskim Parku Narodowym. Folia Turistica Nr 22- 20 Turystyka i ekologia, Akademia Wychowania Fizycznego w Krakowie, Kraków, 25-34, http://yadda.icm.edu.pl/yadda/element/bwmeta1.element.ekon-element-000171467511.

Sotelo Navalpotro, J. S., García Quiroga, F., Sotelo Pérez, M., 2012. Evaluation of Tourism Development in the National Parks of Spain. International Journal of Business and Social Science Vol. 3 No. 14 [Special Issue - July 2012], 1-7, http://www. ijbssnet.com/journals/Vol_3_No_14_Special_Issue_July_2012/1.pdf.

Taczanowska, K., González, L-M., García-Massó, X., Zięba, A., Brandenburg, C., Muhar, A., Pellicer-Chenoll, M., Toca-Herrera, J-L., 2019. Nature-based Tourism or Mass Tourism in Nature? Segmentation of Mountain Protected Area Visitors Using Self-Organising Maps (SOM). Sustainability 2019, 11(5), 1314; https://doi. org/10.3390/su11051314.

Żemła, M., 2010. Wartość dla klienta w procesie kształtowania konkurencyjności obszaru recepcji turystycznej. Górnośląska Wyższa Szkoła Handlowa im. Wojciecha Korfantego, Katowice. 